\title{
RANCANGAN KNOWLEDGE MANAGEMENT SYSTEM DENGAN MENGGUNAKAN THEORETICAL FRAMEWORK DAN PENDEKATAN KONTINGENSI PADA RSU BINTANG KABUPATEN KLUNGKUNG
}

\author{
Anak Agung Gede Putra Dwi Arthajaya ${ }^{1}$, I Made Candiasa ${ }^{2}$, Gede Rasben Dantes ${ }^{3}$ \\ ${ }^{1,2,3}$ Pascasarjana / IImu Komputer, Universitas Pendidikan Ganesha \\ Singaraja, Indonesia
}

e-mail: agoengdwi86@gmail.com ${ }^{1}$,candiasaimade@yahoo.co.id² rasben.dantes@gmail.com ${ }^{3}$

\begin{abstract}
Abstrak
RSU Bintang merupakan rumah sakit binaan pemerintah daerah kabupaten Klungkung. Regulasi pada pemerintah daerah menyebabkan sering terjadi rotasi dan mutasi pegawai. Hal tersebut menyebabkan kehilangan pengetahuan tentang pekerjaan dan pengalaman pegawai serta pengolahannya yang masih belum baik. Oleh karena itu, RSU Bintang membutuhkan sistem yang dapat mengelola pengetahuan pegawai, sehingga diharapkan dapat meminimalkan hilangnya pengetahuan yang dimiliki organisasi. Knowledge Management System (KMS) merupakan salah satu pilihan yang dapat digunakan. Dari persoalan tersebut dirancanglah rancangan prototype KMS dengan menggunakan Theoretical framework dan pendekatan kontingensi. Theoretical framework digunakan dalam mengkombinasikan perancangan milik Fernandez Shaberwal dan Amrit Tiwana. Pendekatan kontingensi dipilih dikarenakan penelitian lebih ditekankan pada proses Knowledge Management. Peneliti mengumpulkan data menggunakan teknik observasi, kuesioner dan wawancara. Hasil akhir dari penelitian ini memprioritaskan pengembangan proses KMS yaitu exchange, direction, socialization for knowledge shering, externalization, routines, combination, dan socialization for knowledge discovery. Fitur yang dihasilkan adalah dokumentasi artikel atau berita, forum diskusi, manajemen dokumen dan manajemen pengetahuan. Hasil uji coba fungsionalitas menggunakan metode UAT mendapat rata 97,8 dan uji coba usability menggunakan metode SUS mendapatkan nilai 75,75 dengan tingkat usability baik. Dari hasil pengujian tersebut digunakan sebagai acuan untuk memberikan rekomendasi untuk dikembangkan KMS pada RSU Bintang.
\end{abstract}

Kata kunci: Knowledge Management System, Theoretical Framewook, Kotingensi

\begin{abstract}
RSU Bintang is a hospital established by the district government at Klungkung. Regulation of district goverment itself mostly causes frequent rotation and mutation of employee, it results loss of working knowledge and experience of employee as well as unorganized processing. Consequently, RSU Bintang needs to require a system that can manage employee knowledge which expected to minimize the loss of knowledge owned by the organization. The use of Knowledge Management System (KMS) is a possibility that can be used. From these cases, a KMS prototype was designed within the Theoretical framework and a contingency approach. Theoretical framework was implemented in combining the development of Fernandez Shaberwal and Amrit Tiwana's design. The contingency approach was selected because this current research was more emphasized on the Knowledge Management process. The data was collected by the researcher through observation technique, questionnaire and interview. The final results of this research focuses on the development of KMS process specifically exchange, direction, socialization for knowledge sharing, externalization, routines, combination, and socialization for knowledge discovery. The feature results are article nor news documentation, discussion forum, document management and knowledge management. The results of the functionality testing using UAT method shows an average number of 97.8 and the usability test using SUS method shows a value of 75.75 with a good usability level. As a conclusion of the test results, this current research can be used as a reference to provide recommendations for developing KMS at RSU Bintang..
\end{abstract}


Keywords : Knowledge Management System, Theoretical Framewook, Kotingensi

\section{PENDAHULUAN}

Kesehatan merupakan prioritas utama yang ingin dicapai oleh setiap orang, bahkan di Indonesia. Pernyataan ini didukung oleh diterbitkannya Peraturan Pemerintah Republik Indonesia No 39 Tahun 2012 tentang penyelenggaraan kesejahteraan sosial khususnya pada pasal 30 yang menyatakan bahwa negara akan memberikan bantuan berupa (a) sandang, pangan, dan Papan; (b) pelayanan kesehatan; (c) penyediaan tempat penampungan sementara; (d) pelayanan terapi psikososial di rumah perlindungan [12].

Mebicarakan tentang kesehatan tidak akan bisa dipisahkan dengan rumah sakit. Industri rumah sakit merupakan industri yang memiliki peran yang sangat penting dalam memberikan pelayanan kesehatan bermutu kepada masyarakat untuk meningkatkan kualitas kesehatan masyarakat [22]. Sesuai dengan Peraturan Menteri Kesehatan no 71 Tahun 2013 pasal 3 tentang penyelenggara pelayanan kesehatan dan pemilihan fasilitas kesehatan bagi pengguna Kartu Indonesia Sehat [11]. Pengguna KIS jika ingin digunakan wajib mendatangi fasilitas kesehatan (Faskes) 1 yang telah ditentukan. Pemilihan Faskes oleh masyarakat tergantung pada lokasi dan kriteria, jenis rumah sakit, puskesmas, dan dapat memilih dokter pribadi. Penanganan yang dilakukan akan secara berjenjang, belum ditangani faskes 1 maka akan diberikan rujukan dan dilanjutkan penanganannya ke rumah sakit kelas $\mathrm{C}$. Rumah Sakit Umum (RSU) Bintang merupakan rumah sakit yang tergolong dalam rumah sakit kelas $\mathrm{C}$ dan instansi pelayanan kesehatan masyarakat yang berada di lingkungan dan binaan pemerintah daerah Kabupaten Klungkung.

Keberadaan RSU Bintang di bawah binaan pemerintah daerah, menyebabkan sering terjadi rotasi dan mutasi pegawai. Hal tersebut menyebabkan kehilangan pengetahuan tentang pekerjaan dan pengalaman pegawai. Pemahaman yang didapat dari pengalaman atau pembelajaran didefinisikan sebagai pengetahuan penting
[3]. Hasil penelitian awal dengan melakukan wawancara terhadap beberapa pimpinan di RSU Bintang menegaskan bahwa pengetahuan merupakan aset penting bagi RSU Bintang sehingga pengelolaannya juga dibutuhkan untuk meminimalisir hilangnya pengetahuan yang dimiliki organisasi. Pengetahuan merupakan Informasi yang telah dianalisis sehingga dapat dimengerti dan dapat digunakan dalam memecahkan masalah maupun menjadi masukan dalam mengambil keputusan [9]. Knowledge management (KM) menjadi sebuah pendekatan yang memungkinkan organisasi dapat mengelola informasi dan pengetahuan dengan lebih baik [7]. Selain itu KM juga dapat berperan sebagai alat bantu dalam proses perubahan atau pun transformasi organisasi, karena KM dapat membantu pembentukan budaya pembelajaran dalam suatu organisasi [2]. KMS memberikan pengaruh positif bagi rumah sakit dan kinerja pegawai [6].

KM membantu organisasi berjalan dengan lebih efisien, lebih kompetitif, dan selalu responsif terhadap perubahan. Perubahan yang cepat terhadap teknologi membuat organisasi menjadi semakin mudah dalam menciptakan, mengumpulkan, memanipulasi, menyimpan, dan mengalirkan banyak data dan informasi. KM dapat meningkatkan efektifitas organisasi dengan menggunakan pengetahuan yang telah dimiliki, baik oleh organisasi maupun individu, dalam meningkatkan kualitas proses pengambilan keputusan dan dapat membantu pembentukan budaya pembelajaran dalam suatu organisasi [5].

Berdasarkan latar belakang masalah yang diuraikan, maka dapat dirumuskan masalah sebagai berikut.

1. Bagaimana rancangan Knowledge Management System (KMS) pada RSU Bintang ?

2. Bagaimana implementasi rancangan Knowledge Management System (KMS) pada RSU Bintang ?

3. Bagaimana hasil pengujian fungsionalitas dan usabilitas Knowledge Management System (KMS) pada RSU Bintang? 


\section{METODE}

Tahapan penelitian yang dilakukan pada penelitian ini seperti Gambar 1 .

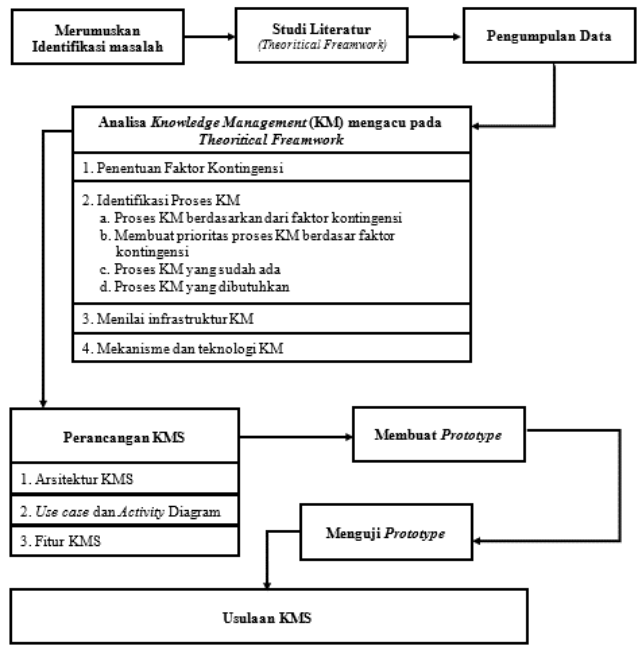

Gambar 1. Tahapan Penelitian

Penelitian yang dilakukan terdiri dari beberapa tahapan. Adapun tahapantahapan penelitian yaitu sebagai berikut.

1. Merumuskan Identifikasi Permasalahan Di tahap ini, peneliti melakukan survey langsung ke RSU Bintang untuk mendapatkan data dan informasi tentang permasalahan yang ada di RSU Bintang.

2. Melakukan Studi Literatur

Dalam membuat penelitian, Theoretical freamwork merupakan output dari hasil tinjauan pustaka. Langkah-langkah dalam perancangan Theoretical freamwork adalah sebagai berikut.

a. Mengidentifikasi masalah.

Permasalahan yang diteliti adalah metode dalam perancangan knowledge management system.

b. Mencari variabel yang terkait permasalahan dengan melakukan tinjauan pustaka dari penelitian sebelumnya. Variabel dibedakan menjadi 2 (dua) jenis.

1). Dependent Varible

Pengembangan knowledge management system (KMS).

2). Independent Variable

Langkah yang dilakukan pada pengembangan KMS dengan menggunakan metode Amrit Tiwana dengan 9 langkah dalam empat tahapan utama [13] dan Fernandez Sabherwal.

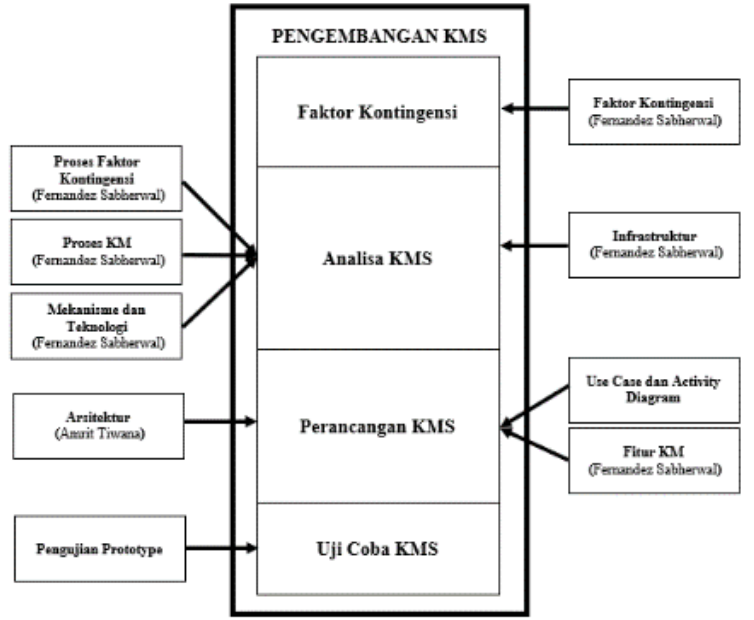

Gambar 2. Theoretical freamwork

3. Melakukan pengumpulan data

Data yang digunakan dalam penelitian adalah data primer dan data sekunder. Data primer yaitu data yang dikumpulkan secara langsung oleh peneliti. Data primer didapat dari observasi, wawancara dan kuesioner, sedangkan data sekunder diperoleh dari dokumen-dokumen RSU Bintang yang terkait dengan penelitian. Teknik pengumpulan data yang digunakan sebagai berikut.

a. Observasi

Dengan melakukan pengamatan terhadap lingkungan kerja, baik secara langsung maupun dengan dokumen yang ada, serta dengan studi literatur.

b. Wawancara

Dengan melakukan interview kepada Direktur, Kabag Pelayanan Medis, Kabag Umum dan SDM, dan Kanit Humas dan Marketing tentang kondisi pengelolaan pengetahuan di RSU Bintang.

c. Kuesioner

Responden kuesioner adalah pegawai dan praktisi klinis RSU Bintang pada Bagian Pelayanan Medik, Bagian Sumber Daya Manusia, Bagian Umum, Humas dan Marketing. Kuesioner yang digunakan mengadopsi kuesioner milik Theresia Puspa Wijayanti dalam penelitian Wijayanti [15] karena dalam kuesioner tersebut memetakan faktor kontingensi dan 
proses knowledge management yang digunakan pada penelitian ini. Kuesioner terdiri dari tujuh bagian, yaitu data diri responden, kebutuhan akan knowledge management, faktor kontingensi organisasi, fitur-fitur knowledge management system yang dibutuhkan, penggalian proses knowledge management yang ada, lingkungan fisik organisasi dalam membantu proses transfer pengetahuan, dan peran serta responden dalam aktivitas komunitas.

\section{Melakukan Analisis Knowledge} Management

a. Menentukan faktor kontingensi dengan melihat karakteristik tugas, pengetahuan, lingkungan dan organisasi. Penentuan faktor-faktor kontingensi diperoleh dari data kuesioner dan wawancara. Hasil dari proses ini adalah faktor-faktor kontingensi (task characteristics, knowledge characteristics dan organizational and environmental characteristics).

b. Melakukan identifikasi proses $K M$.

1) Proses knowledge management berdasarkan dari faktor-faktor kontingensi yang telah didapat sebelumnya. Metode yang dilakukan dengan menganalisis faktor- faktor kontigensi menggunakan Tabel faktor kontingensi. Hasil yang didapat berupa portofolio proses knowledge management.

2) Membuat prioritas proses knowledge management yang dibutuhkan berdasarkan kesesuaian dengan masingmasing faktor kontingensi. Hasil dari proses ini berupa portofolio prioritas proses knowledge management yang dibutuhkan.

3) Mengidentifikasi proses knowledge management yang sudah ada dan telah dimanfaatkan masing-masing individu dalam menunjang pekerjaannya. Hasil dari proses ini adalah portofolio proses knowledge management yang sudah ada.

4) Melakukan identifikasi proses knowledge management tambahan yang dibutuhkan berdasarkan portofolio proses knowledge management yang sudah ada untuk meningkatkan prioritas knowledge management yang dibutuhkan organisasi.

c. Menilai infrastruktur KM dilakukan dengan metode wawancara dan observasi. Wawancara dan observasi digunakan untuk melihat gambaran infrastruktur knowledge management yang ada pada organisasi seperti budaya organisasi, pengetahuan umum, struktur organisasi, infrastruktur $\mathrm{TI}$ dan lingkungan fisik organisasi.

d. Mengembangkan KMS yang dibutuhkan berikut dengan mekanisme dan teknologi. Pada proses ini dilakukan berdasarkan keseluruhan informasi mengenai area pengembangan knowledge management beserta infrastrukturnya. Hasil dari proses ini yaitu fitur-fitur KMS, mekanisme knowledge management dan model KMS.

5. Perancangan KMS

Pada langkah ini melakukan perancangan KMS RSU Bintang yang sesuai dengan proses knowledge management, model dan teknologi arsitektur KMS. Kemudian menganalisis kebutuhan sistem dan memetakan proses knowledge management yang dibutuhkan dengan mekanisme knowledge management dalam organisasi dan fitur sistem yang dibutuhkan. Setelah itu dibuat use case diagram dan activity diagram berdasarkan fitur sistem tersebut. Berdasarkan kebutuhan KMS yang telah teridentifikasi, dilakukan perancangan KMS. 
6. Membuat prototype KMS

Pada langkah ini dirancang prototype KMS RSU Bintang. Proses dilakukan dengan input yaitu rancangan model KMS dan output berupa prototype KMS.

7. Uji coba prototype KMS

Pada langkah ini dilakukan uji coba dengan menggunakan metode User Acceptance Testing (UAT) dan System Usability Scale (SUS) atas prototype yang telah dibuat sebelumnya. Usability digunakan untuk mengukur kualitas suatu sistem, perangkat lunak maupun website, berkaitan dengan kemudahan dalam mempelajari dan menggunakan sistem [8]. Pengujian dilakukan kepada pakar dan beberapa calon pengguna, yaitu pakar diambil 3 (tiga) penguji yang terbiasa berkecimpung sebagai pengembang sistem dan 17 pegawai RSU Bintang dengan melakukan pemilihan calon penguji menggunakan metode accidental sampling, untuk melakukan tes atas fitur-fitur prototype KMS. Pengujian dilakukan kepada 20 responden, jumlah tersebut sudah mencukupi untuk mengukur usability. Tidak ada jumlah responden yang pasti dalam pengukuran usability, akan tetapi aturan $16 \pm 4$ (artinya jumlah responden antara 16 - 4 sampi dengan $16+4$ ) menghasilkan hasil uji dengan validitas yang tinggi [1].

\section{HASIL DAN PEMBAHASAN}

\section{Analisa Data}

Metode yang digunakan untuk menganalisis data hasil kuesioner adalah dengan pendekatan deskripsi kualitatif dan kuantitatif. Pendekatan deskripsi kualitatif didapat dari hasil wawancara dengan beberapa kepala satuan pelaksana dan kepala bagian. Pendekatan kuantitatif dihasilkan dari analisis kuesioner yang telah disebar ke responden, yaitu pada Bagian Sumber Daya Manusia, Bagian Umum, Humas dan Marketing, Unit Instalasi Gawat Darurat, Unit Rawat Inap dan Kamar Bersalin pada Bagian Pelayanan Medik.
2. Identifikasi Faktor Kontingensi

Identifikasi faktor kontingensi dilakukan dengan cara menganalisis task characteristics, knowledge characteristics dan organizational and environmental characteristics.

a. Analisa Karakter Tugas



Gambar 3. Analisa Ketidakpastian Tugas (Task Uncertainty)

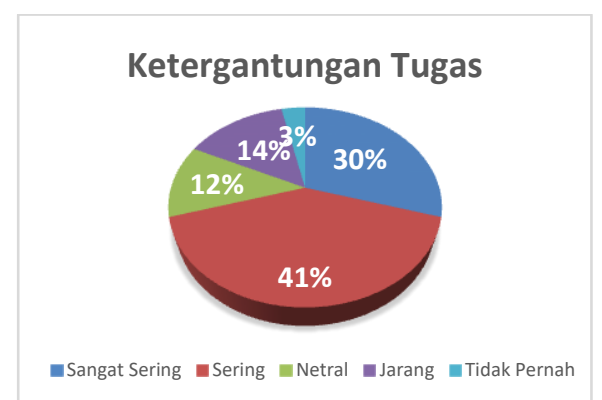

Gambar 4. Analisa Ketergantungan Tugas (Task Interdependence)

Dari analisa karakter tugas yang sudah dilakukan didapatkan, ketidakpastian tugas tergolong jarang dan ketergantungan tugas sering.

b. Analisa Karakter Pengetahuan

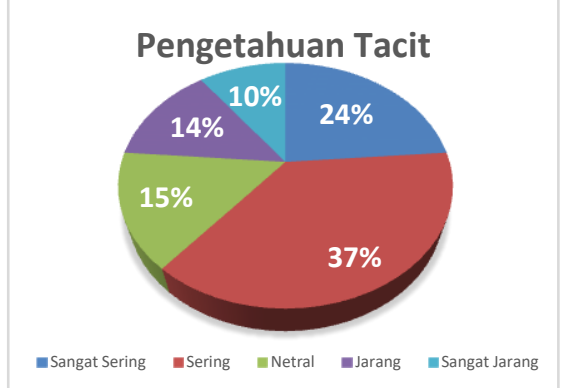

Gambar 5. Analisa Pengetahuan Tacit 


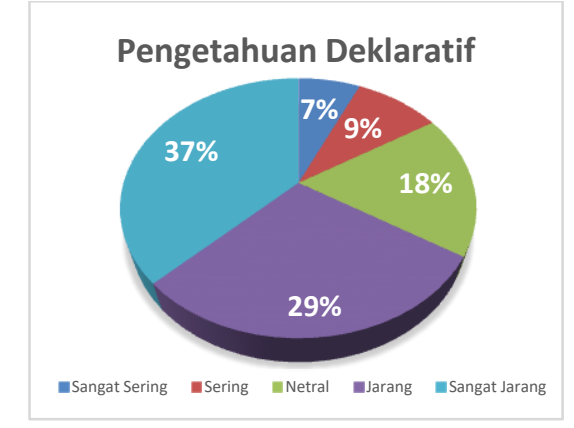

Gambar 6. Analisa Pengetahuan Deklaratif

Dari analisa karakter pengetahuan didapatkan bahwa shering pengetahuan cenderung didapatkan secara langsung/tacit dan sangat jarang bersifat deklaratif atau cenderung ke procedural.

c. Analisa Karakter Organisasi

Karakteristik organisasi ditentukan dengan menggunakan dua parameter acuan, yaitu ukuran organisasi dan strategi bisnis organisasi. Robbins (1990) mengemukakan bahwa suatu organisasi dikatakan berukuran besar jika memiliki karyawan dengan jumlah minimal 1500 karyawan dan berukuran kecil jika memiliki karyawan dengan jumlah kurang dari 1500 orang. Total pegawai dan praktisi klinis yang dimiliki RSU Bintang adalah 172 orang (Profil RSU Bintang tahun 2019). Oleh karena itu, RSU Bintang dikategorikan sebagai organisasi yang memiliki ukuran yang kecil.

d. Analisa Karakter Lingkungan (Environmental Uncertainty)

Karaktertistik lingkungan organisasi dipengaruhi oleh pihak luar terhadap pengelolaan organisasi [10]. RSU Bintang memiliki keterkaitan dengan pihak luar seperti Pemerintah Daerah, BPJS, perusahaan asuransi swasta, perusahaan farmasi, dan lain sebagainya dalam hal peraturan dan kebijakan-kebijakan yang berlaku.

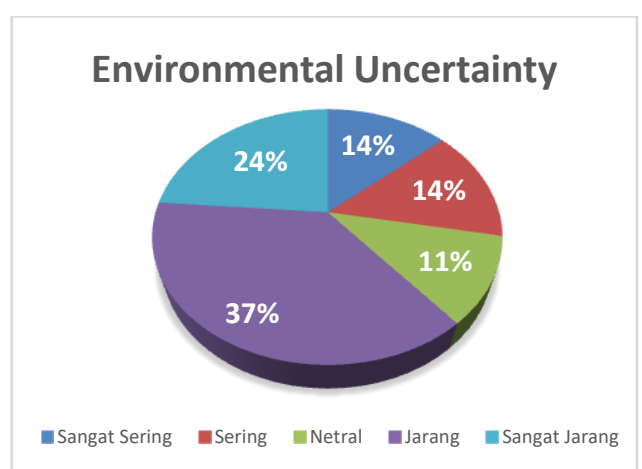

Gambar 7. Analisa Karakter Lingkungan (Environmental Uncertainty)

Berdasarkan hasil $\begin{array}{r}\text { analisis } \\ \text { responden disimpulkan } \\ \text { Environmental }\end{array}$
Cncertainty lebih
cenderung jarang/rendah.

3. Identifikasi Proses KM Berdasarkan Faktor Kontingensi

Setelah didapatkan hasil analisa faktor kontingensi, kemudian diselaraskan dengan tabel prioritas $\mathrm{KM}$ yang dimiliki oleh Fernandez dan Subherwal. Hasil penyelasaran ditunjukkan pada Tabel 2 .

Tabel 2. Identifikasi Proses Faktor Kontingensi

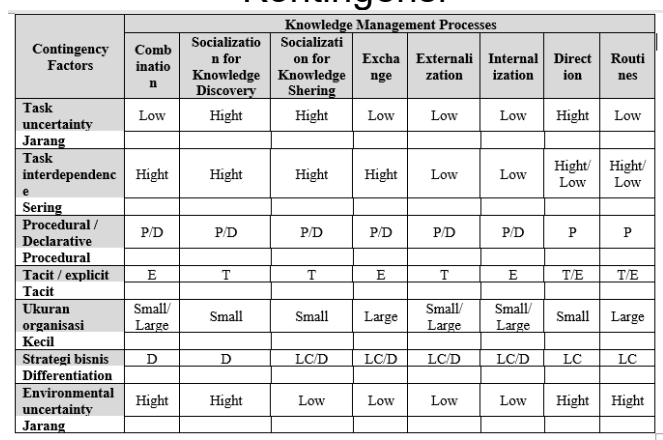

4. Melakukan Prioritas Proses KM Yang Dibutuhkan

Setelah mengidentifikasi proses KM berdasarkan faktor kontingensi, langkah selanjutnya adalah menentukan prioritas proses KM yang dibutuhkan.

a. Pemberian skor yes, ok dan no.

b. Pemberian skor yes $=1$, ok $=0,5$ dan no $=0$.

Hasil penskoran ditunjukkan pada Tabel 3. 
Tabel 3. Prioritas Proses KM

\begin{tabular}{|c|c|c|c|c|c|c|c|c|}
\hline \multirow{2}{*}{ 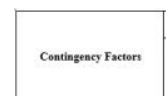 } & \multicolumn{8}{|c|}{ 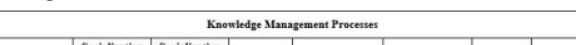 } \\
\hline & \\
\hline & ves & & & & Vits & 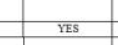 & & \\
\hline & & vis & Yis & vis & so & & & \\
\hline W/D & & 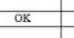 & & & ok & ox & & \\
\hline & so & vis & YES & so & YES & No & & \\
\hline  & ok & Yis & YES & so & & ok & & \\
\hline fiblibutic & & so & ok & ok & ok & ok & & \\
\hline 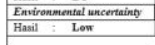 & so & \$No & 2 ist & Yits & VES & Yis & & \\
\hline 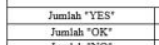 & $\frac{2}{2}$ & $\frac{3}{1}$ & $\frac{4}{2}$ & & $\frac{3}{3}$ & & & \\
\hline 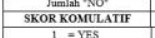 & & & & & & & & \\
\hline 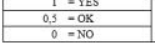 & 3 & 3,5 & 5 & 4 & 4 & 3,5 & 4 & \\
\hline \multirow{9}{*}{\multicolumn{9}{|c|}{\begin{tabular}{llr} 
Tahapan selanjutnya adalah & \multicolumn{2}{c}{ ada } \\
memberikan prioritas prosses KM \\
berdasarkan total skor kumulatif. \\
Pemberian prioritas proses KM \\
dilakukan dengan menghitung \\
persentase tiap skor kumulatif yang \\
diperoleh dibagi dengan maksimal \\
skor standar masing-masing proses \\
KM kemudian ditandai dengan \\
peringkat prioritas sesuai dengan \\
persentase tertinggi.
\end{tabular}}} \\
\hline & & & & & & & & \\
\hline & & & & & & & & \\
\hline & & & & & & & & \\
\hline & & & & & & & & \\
\hline & & & & & & & & \\
\hline & & & & & & & & \\
\hline & & & & & & & & \\
\hline & & & & & & & & \\
\hline \multicolumn{9}{|c|}{ 「abel 4. Proses KM Faktor Kon } \\
\hline \multirow{2}{*}{\multicolumn{2}{|c|}{$\begin{array}{l}\text { Proses Knowledge } \\
\text { Management }\end{array}$}} & & \multicolumn{6}{|c|}{ Knowledge Management $P$} \\
\hline & & & \begin{tabular}{l|l} 
Skor \\
Skmplaif
\end{tabular} & & & rsentase & & \\
\hline \multirow{2}{*}{\multicolumn{2}{|c|}{$\begin{array}{l}\text { Combination } \\
\text { Socialization for Knowledge }\end{array}$}} & & & & & $50.00 \%$ & & \\
\hline & & & 3.5 & & & & & \\
\hline \multicolumn{2}{|c|}{ ion for Knowledge } & & & & & & & \\
\hline \multicolumn{2}{|c|}{$\begin{array}{l}\text { Shering } \\
\text { Exchange } \\
\text { Externalization }\end{array}$} & & & & & & & \\
\hline & & 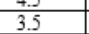 & & & & & \\
\hline & & 0 & & & & & \\
\hline & & & & & & & & \\
\hline
\end{tabular}

5. Identifikasi Proses Knowledge Saat Ini Pengidentifikasian proses knowledge yang ada di RSU Bintang saat ini dilakukan dengan cara menganalisis hasil kuesioner. Pertanyaan dalam kuesioner yang mengacu pada pengidentifikasian ini berada pada pertanyaan bagian ke IV soal 1 sampai soal ke 16, di mana responden diwajibkan untuk memilih salah satu dari pilihan jawaban yang tersedia.
Tabel 5.Proses Knowledge Saat ini

\begin{tabular}{|l|c|c|c|c|}
\hline \multirow{2}{*}{$\begin{array}{c}\text { Proses Knowledge } \\
\text { Management }\end{array}$} & \multicolumn{4}{|c|}{ Knowledge Management Processes } \\
\cline { 2 - 5 } & $\begin{array}{c}\text { Skor } \\
\text { Kumulatif }\end{array}$ & $\begin{array}{c}\text { Maksimum } \\
\text { Skor }\end{array}$ & Persentase & Peringkat \\
\hline Combination & 3.53 & 5.00 & $70.51 \%$ & 4 \\
\hline $\begin{array}{l}\text { Socialization for } \\
\text { Knowledge Discovery }\end{array}$ & 3.77 & 5.00 & $75.42 \%$ & 1 \\
\hline $\begin{array}{l}\text { Socialization for } \\
\text { Knowledge Shering }\end{array}$ & 3.13 & 5.00 & $62.54 \%$ & 6 \\
\hline Exchange & 3.55 & 5.00 & $71.02 \%$ & 3 \\
\hline Externalization & 2.46 & 5.00 & $49.15 \%$ & 8 \\
\hline Internalization & 3.28 & 5.00 & $65.59 \%$ & 5 \\
\hline Direction & 3.57 & 5.00 & $71.36 \%$ & 2 \\
\hline Routines & 2.55 & 5.00 & $51.02 \%$ & 7 \\
\hline
\end{tabular}

6. Mengidentifikasi Tambahan Proses KM Yang Dibutuhkan

Tahapan ini dilakukan untuk mengetahui identifikasi proses KM tambahan yang akan dikembangkan. Proses identifikasi proses KM tambahan dilakukan dengan membandingkan hasil dari proses KM Faktor Kontingensi (Tabel 4) dengan proses KM Saat ini (Tabel 5). Untuk menentukan proses $\mathrm{KM}$ yang akan menjadi prioritas pengembangan oleh RSU Bintang, maka langkah yang harus dilakukan pertama adalah membagi peringkat proses KM menjadi dua kelompok. Kelompok kebutuhan tinggi jika memiliki peringkat 1 sampai 5 dan kelompok kebutuhan rendah jika memiliki peringkat 6 sampai 8 . Langkah selanjutnya membagi peringkat proses KM, jika proses KM faktor kontingensi tinggi dan proses $\mathrm{KM}$ saat ini tinggi, maka diberi peringkat 1 (prioritas pengembangan pertama), jika proses KM faktor kontingensi tinggi dan proses KM saat ini rendah, maka diberi peringkat 2 (dikembangkan setelah prioritas 1 sudah dikembangkan),jika proses KM faktor kontingensi rendah dan proses KM saat ini tinggi, maka diberi peringkat 3 (dikembangkan jika sumber daya sudah tersedia), dan jika proses KM faktor kontingensi rendah dan proses KM saat ini rendah, maka 
diberi peringkat 4 (tidak perlu dikembangkan).

Tabel 6. Tambahan Proses KM Setelah Dikategorikan

\begin{tabular}{|l|l|c|c|c}
\hline \multirow{2}{*}{$\begin{array}{c}\text { Aktivitas } \\
\text { KM }\end{array}$} & \multirow{2}{*}{ Proses KM } & \multicolumn{2}{|c|}{$\begin{array}{c}\text { Knowledge Management } \\
\text { Processes }\end{array}$} & \multirow{2}{*}{ Peringkat } \\
\cline { 3 - 5 } & & $\begin{array}{c}\text { Yang } \\
\text { Dibutuhkan }\end{array}$ & Saat Ini & \\
\hline \multirow{3}{*}{ Discovery } & Combination & Rendah & Tinggi & 3 \\
\cline { 2 - 5 } & $\begin{array}{l}\text { Socialization for } \\
\text { Knowledge Discovery }\end{array}$ & Rendah & Tinggi & 3 \\
\hline \multirow{2}{*}{ Sharing } & $\begin{array}{l}\text { Socialization for } \\
\text { Knowledge Shering }\end{array}$ & Tinggi & Rendah & 2 \\
\cline { 2 - 5 } & Exchange & Tinggi & Tinggi & 1 \\
\hline \multirow{2}{*}{ Capture } & Externalization & Tinggi & Rendah & 2 \\
\cline { 2 - 5 } & Internalization & Rendah & Rendah & 4 \\
\hline \multirow{2}{*}{ Application } & Direction & Tinggi & Tinggi & 1 \\
\cline { 2 - 5 } & Routines & Tinggi & Rendah & 2 \\
\hline
\end{tabular}

7. Analisa Infrastruktur KM Infrastruktur KM yang dianalisa adalah sebagai berikut.

a. Budaya Organisasi

Adanya dukungan, reward dari pihak managerial dalam proses KM. Reward digunakan sebagai pemancing pegawai agar loyal membagikan pengetahuan yang dimiliki.

b. Struktur Organisasi

Atribut yang dianalisa adalah hirarki dan community of practice. Organisasi menganut hirarki sentralisasi dan hsail community of practice seperti pada tabel 6.

Tabel 7. Peran serta community of practice

\begin{tabular}{|l|c|l|}
\hline \multicolumn{1}{|c|}{ Peran Aktif } & $\begin{array}{c}\text { Jumlah } \\
\text { Responden }\end{array}$ & Persentase \\
\hline Memberi arahan dan masukan & 43 & $36.4 \%$ \\
\hline Peran aktif membagi pengetahuan melalui lisan & 68 & $57.6 \%$ \\
\hline Peran aktif membagi pengetahuan melalui tulisan & 70 & $59.3 \%$ \\
\hline $\begin{array}{l}\text { Peran aktif mendapatkan pengetahuan dalam } \\
\text { pertemuan langsung }\end{array}$ & 62 & $52.5 \%$ \\
\hline $\begin{array}{l}\text { Peran aktif mendapatkan pengetahuan dengan } \\
\text { membaca dokumen }\end{array}$ & 47 & $39.8 \%$ \\
\hline Peran lain & 2 & $1.7 \%$ \\
\hline
\end{tabular}

c. Teknologi Informasi

Atribut yang dianalisa adalah reach, depth, richness dan aggregation.

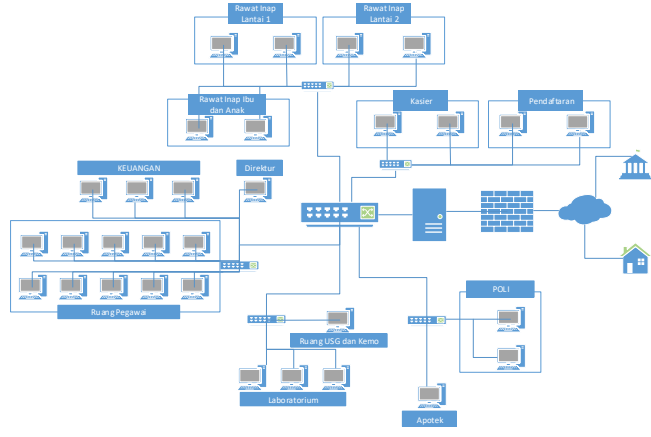

Gambar 8. Topologi Jaringan

d. Pengetahuan Umum

Atribut pengetahuan yang dianalisa adalah dikelompokkan menjadi people, artifact dan organizational entities [4].

8. Mengembangkan Sistem, Mekanisme, dan Teknologi KM yang Dibutuhkan Tabel 7. Pemetaan Teknologi KM

\begin{tabular}{|c|c|c|c|}
\hline $\begin{array}{l}\text { Proses } \\
\text { KM }\end{array}$ & Penjelasan & $\begin{array}{c}\text { Mekanisme } \\
\text { KM }\end{array}$ & $\begin{array}{c}\text { Teknologi } \\
\text { KM }\end{array}$ \\
\hline $\begin{array}{l}\text { Exchang } \\
\text { e }\end{array}$ & $\begin{array}{l}\text { Pertukaran } \\
\text { pengetahua } \\
\mathrm{n} \text { explicit } \\
\text { antar } \\
\text { karyawan }\end{array}$ & $\begin{array}{l}\text { Memo, } \\
\text { presentasi, } \\
\text { surat artikel, } \\
\text { user manual }\end{array}$ & $\begin{array}{l}\text { Manajemen } \\
\text { dokumen, } \\
\text { Manajemen } \\
\text { artikel/berita, } \\
\text { Pencarian } \\
\text { dokumen } \\
\text { dan artikel } \\
\end{array}$ \\
\hline Direction & $\begin{array}{l}\text { Mendapatka } \\
\mathrm{n} \text { bantuan } \\
\text { dalam } \\
\text { menyelesaik } \\
\text { an } \\
\text { permasalah } \\
\text { an dalam } \\
\text { pekerjaan } \\
\text { tanpa } \\
\text { menyalurkan } \\
\text { knowledge } \\
\text { yang dimiliki. }\end{array}$ & $\begin{array}{l}\text { Pusat } \\
\text { bantuan, } \\
\text { help desk }\end{array}$ & $\begin{array}{l}\text { Forum, } \\
\text { Manajemen } \\
\text { pengetahua } \\
\mathrm{n}\end{array}$ \\
\hline $\begin{array}{l}\text { Socializ } \\
\text { ation for } \\
\text { knowled } \\
\text { ge } \\
\text { sharing }\end{array}$ & $\begin{array}{l}\text { Interaksi } \\
\text { antar } \\
\text { karyawan } \\
\text { dalam } \\
\text { membagi } \\
\text { pengetahua } \\
\text { n yang } \\
\text { dimilikinya } \\
\end{array}$ & $\begin{array}{l}\text { Rotasi } \\
\text { karyawan, } \\
\text { diskusi, } \\
\text { brainstormin } \\
\text { g }\end{array}$ & $\begin{array}{l}\text { Forum } \\
\text { diskusi, } \\
\text { Mailing list, } \\
\text { Chatting, } \\
\text { Video } \\
\text { Conference }\end{array}$ \\
\hline $\begin{array}{l}\text { Externali } \\
\text { zation }\end{array}$ & $\begin{array}{l}\text { Menuangka } \\
\mathrm{n} \\
\text { pengetahua } \\
\mathrm{n} \text { yang } \\
\text { dimiliki ke } \\
\text { dalam } \\
\text { bentuk } \\
\text { dokumen }\end{array}$ & $\begin{array}{l}\text { Pengalaman } \\
\text {, best } \\
\text { practices, } \\
\text { lesson } \\
\text { learned }\end{array}$ & $\begin{array}{l}\text { Manajemen } \\
\text { pengetahua } \\
\mathrm{n} \text {, Forum }\end{array}$ \\
\hline Routines & $\begin{array}{l}\text { Menggunak } \\
\text { an } \\
\text { pengetahua } \\
\text { n yang ada }\end{array}$ & $\begin{array}{l}\text { Kebijakan } \\
\text { organisasi, } \\
\text { SOP, } \\
\text { pengalaman }\end{array}$ & $\begin{array}{l}\text { Manajemen } \\
\text { pengetahua } \\
\mathrm{n}, \\
\text { Manajemen } \\
\end{array}$ \\
\hline
\end{tabular}

Jurnal Nasional Pendidikan Teknik Informatika : JANAPATI | 358 


\begin{tabular}{|c|c|c|c|}
\hline $\begin{array}{c}\text { Proses } \\
\text { KM }\end{array}$ & \multirow{2}{*}{$\begin{array}{l}\text { Penjelasan } \\
\text { dalam } \\
\text { prosedur } \\
\text { kerja atau } \\
\text { pun SOP } \\
\text { yang ada }\end{array}$} & \multirow{2}{*}{$\begin{array}{l}\text { Mekanisme } \\
\text { KM } \\
\text { kerja }\end{array}$} & \multirow{2}{*}{ 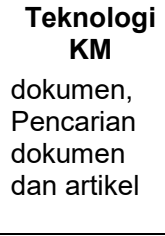 } \\
\hline & & & \\
\hline $\begin{array}{l}\text { Combin } \\
\text { ation }\end{array}$ & $\begin{array}{l}\text { Melakukan } \\
\text { suatu } \\
\text { kolaborasi } \\
\text { untuk } \\
\text { menciptakan } \\
\text { pengetahua } \\
\text { n baru dari } \\
\text { pengetahua } \\
\text { n yang } \\
\text { sudah ada }\end{array}$ & $\begin{array}{l}\text { Rapat, } \\
\text { diskusi, } \\
\text { dokumen, } \\
\text { pembuatan } \\
\text { dokumen }\end{array}$ & $\begin{array}{l}\text { Manajemen } \\
\text { dokumen, } \\
\text { Dokumentas } \\
\text { i artikel, } \\
\text { Forum } \\
\text { diskusi }\end{array}$ \\
\hline $\begin{array}{l}\text { Socializ } \\
\text { ation for } \\
\text { knowled } \\
\text { ge } \\
\text { discover } \\
y\end{array}$ & $\begin{array}{l}\text { Interaksi } \\
\text { karyawan } \\
\text { untuk } \\
\text { mendapatka } \\
\text { n } \\
\text { pengetahua } \\
\text { n baru }\end{array}$ & $\begin{array}{l}\text { Rotasi } \\
\text { karyawan, } \\
\text { diskusi, } \\
\text { brainstormin } \\
\text { g }\end{array}$ & $\begin{array}{l}\text { Forum } \\
\text { diskusi, } \\
\text { Mailing list, } \\
\text { Chatting, } \\
\text { Video } \\
\text { Conference }\end{array}$ \\
\hline
\end{tabular}

Mekanisme yag dibutuhkan adalah sebagai berikut.
a. Komitmen dari pimpinan untuk mendukung proses $\mathrm{KM}$
b. Adanya regulasi mengenai penerapan dan penggunaan KMS
c. Memberikan reward kepada pegawai
d. Mengikutkan pegawai dalam pendidikan, pelatihan, seminar.
e. Melakukan meeting tiap bulan
f. Melakukan evaluasi terhadap penerapan dan penggunaan KMS

9. Model (KMS)

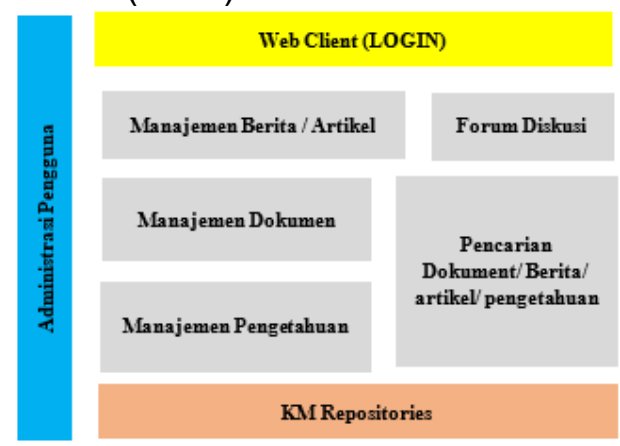

Gambar 9. Model KMS

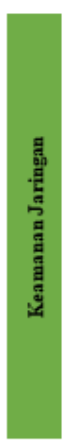

10. Analisa Kebutuhan Sistem

Analisa kebutuhan sistem KMS dibagi menjadi 2 (dua) kenutuhan, yaitu kebutuhan fungsional dan kebutuhan non fungsional.
a. Kebutuhan Fungsional
Kebutuhan fungsional atau fuctional requirement adalah

deskripsi aktifitas dan layanan yang disediakan oleh sistem. Kebutuhan fungsional dari KMS RSU Bintang merupakan aktifitas yang didapatkan dari model KMS

b. Kebutuhan Non Fungsional

Kebutuhan non fungsional atau non functional requirement adalah deskripsi dari fitur-fitur, karakteristik, dan merupakan kebutuhan yang merujuk pada sifat-sifat yang dimiliki oleh sistem.

11. Use Case Diagram

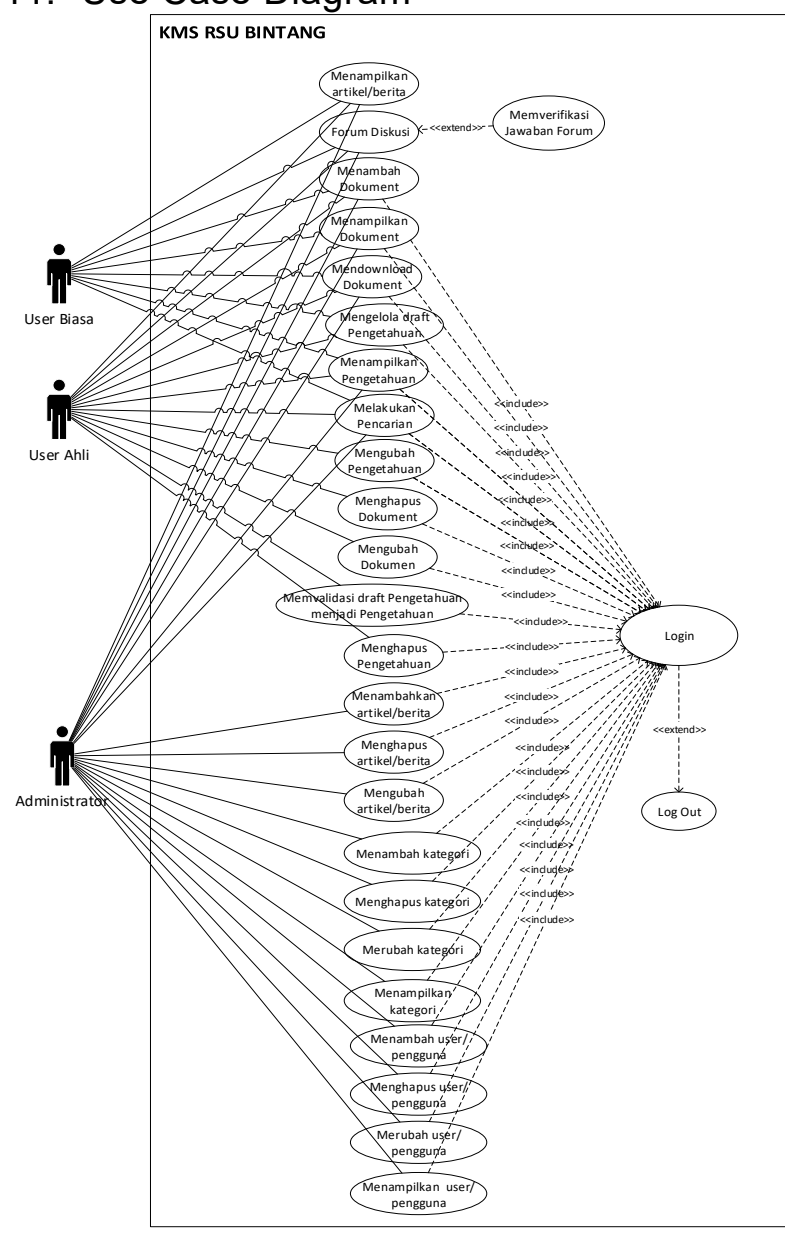

Gambar 10.Use Case KMS

12. Rancangan Aktivity Diagram Activity diagram dibuatkan dari use case yang sudah dijelaskan pada Gambar 9.

13. Perancangan Teknologi Arsitektur KMS

Dalam merancang teknologi Arsitektur KMS penulis mengadopsi teori Amrit. Dalam teori tersebut dijelaskan bahwa 
teknologi arsitektur KMS terdiri dari 7 (tujuh) lapisan [13].

a. Interface Layer

Lapisan ini merupakan lapisan paling luar sehingga menjadi tempat berinteraksi antara user/pengguna dengan KMS RSU Bintang.

b. Access And Authentication Layer Pada lapisan ke-2 (dua) adalah lapisan dimana proses pengecekan autentikasi terjadi untuk mengakses sistem.

c. Collaborative Intelligence And Filtering Layer

Lapisan yang ke-3 (tiga) merupakan lapisan dimana proses penyimpanan, penamaan metadata, dan penyaringan dilakukan.

d. Application Layer

Lapisan yang ke-4 (empat) adalah pengintegrasian aplikasi yang digunakan dalam pengembangan KMS.

e. Transport Layer

Lapisan ke-5 (lima) merupakan lapisan yang mengatur komunikasi antara user/pengguna dengan KMS.

f. Middleware And Legacy Layer

Middleware and legacy layer ini merupakan lapisan untuk mengintegrasikan sistem yang memiliki platform yang berbeda yang ada pada organisasi menjadi satu kesatuan.

g. Repository

Lapisan terakhir adalah lapisan inti yang menjadi tempat penyimpanan data, informasi dan pengetahuan yang ada pada sistem.

14. Perancangan Infrastruktur KMS

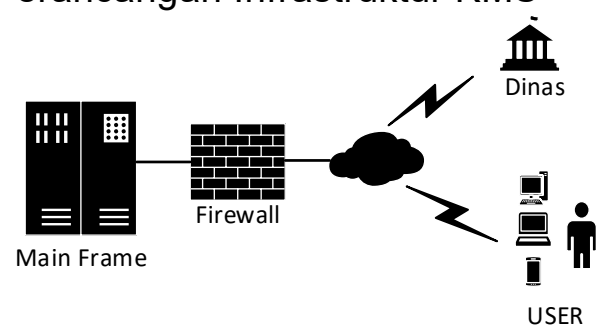

Gambar 10. Infrastruktur KMS

15. Perancangan Database KMS

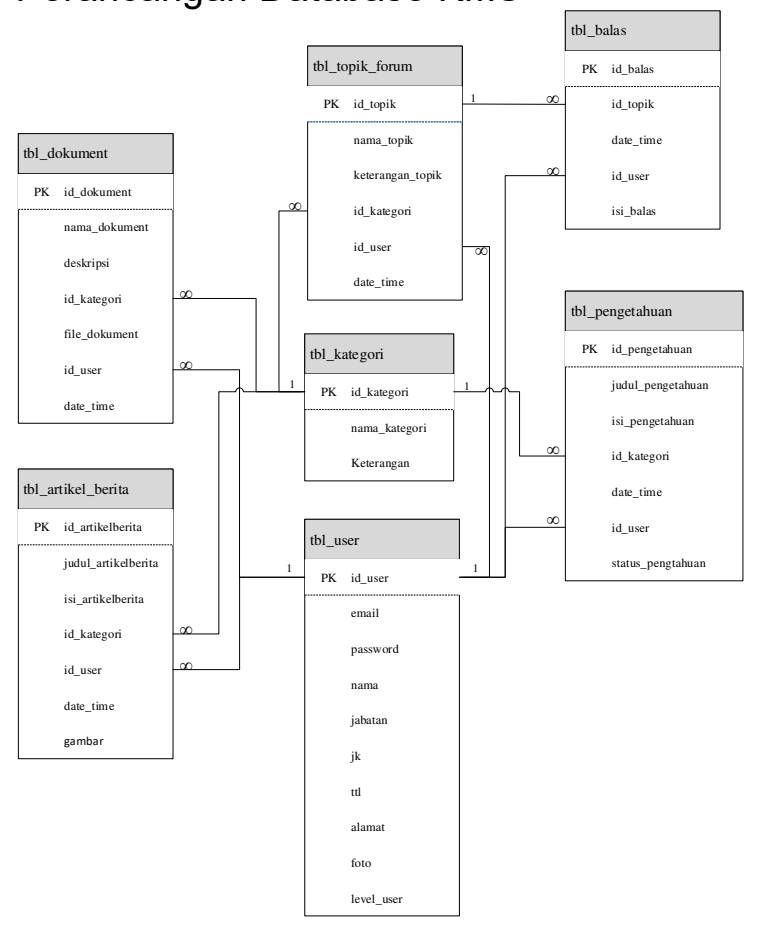

Gambar 12. Rancangan Database

16. Rancangan Tampilan Prototype KMS

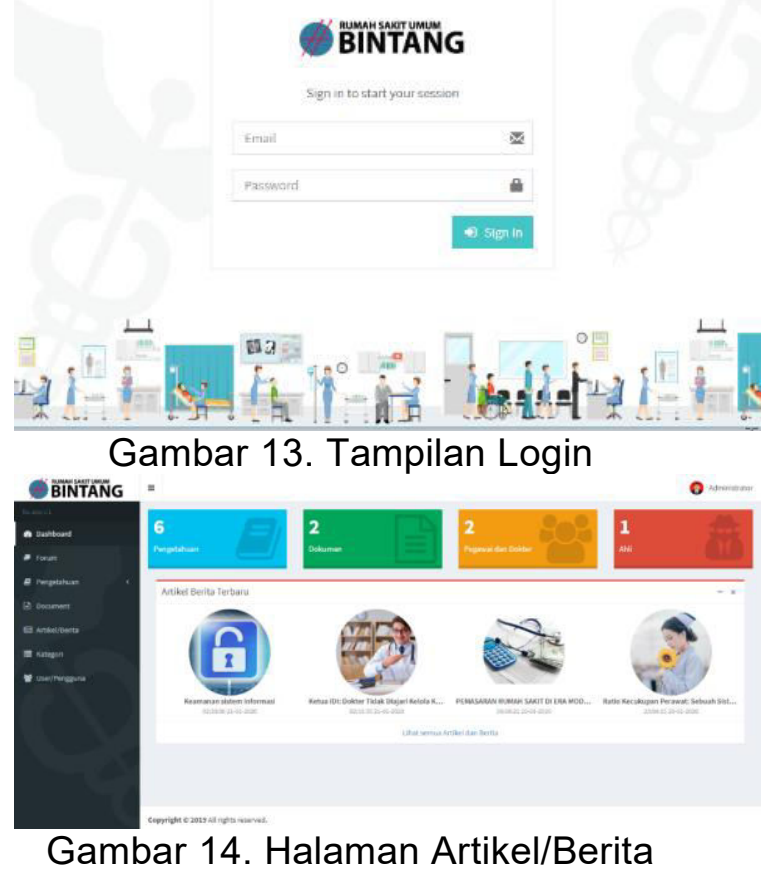




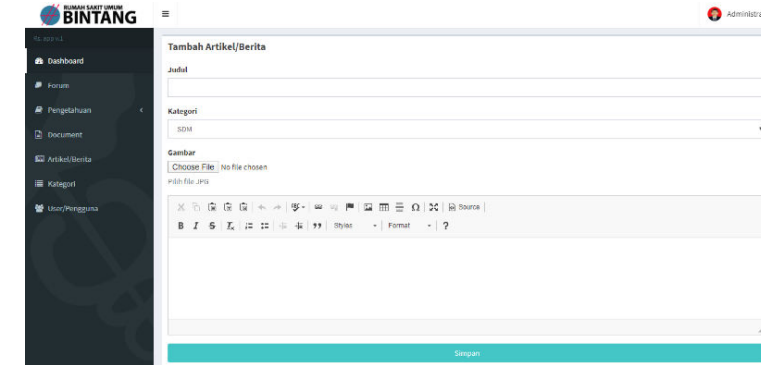

Gambar 15. Halaman Menambah Artikel/Berita

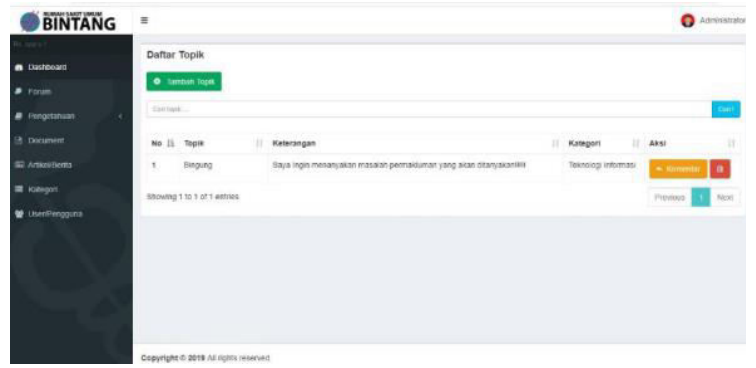

Gambar 16. Halaman Khusus User Forum

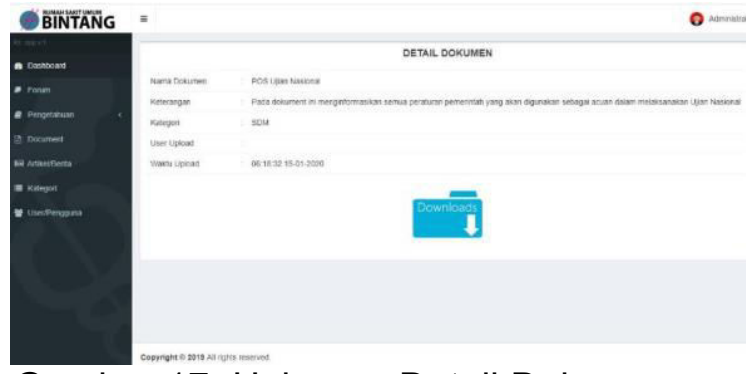

Gambar 17. Halaman Detail Dokumen

17. Uji Coba Rancangan KMS

Pengujian rancangan KMS pada RSU Bintang menggunakan metode UAT untuk menguji fungsionalitas firtur-fitur yang sudah ditentukan sebelumnya dan mengabaikan proses detail internal sistem didalamnya. Dan selanjutnya dilakukan pengujian usability menggunakan metode SUS. Proses pengujian dilakuakn pada ruangan yang sudah disiapkan prototype KMS dan form tugas yang dikerjakan serta form penilaian.

a. Pengujian dengan metode UAT diperuntuhkan untuk menguji fungsionalitas KMS. Penilaian pengujian dibagi menjadi 3 (tiga), yaitu (1) nilai 1 (satu) jika tidak setuju, (2) nilai 2 (dua) setuju dengan catatan dan (3) nilai 3 (tiga) setuju tanpa catatan.
Hasil dari pengujian UAT yang telah dilakukan dapat ditarik kesimpulan sebagai berikut. (1) Semua fitur prototype yang yang dapat dijalankan mendapatkan skor akhir 95,0. (2) Prototype dapat membantu pengelolaan pengetahuan mendapatkan skor akhir 98,3. (3) Prototype sesuai dengan kebutuhan mendapatkan skor akhir 100 dan tidak mendapatkan catatan.

b. Pengujian SUS

Pengujian SUS terdiri dari 10 pertanyaan.

Tabel 8. Hasil Skor Pengujian SUS

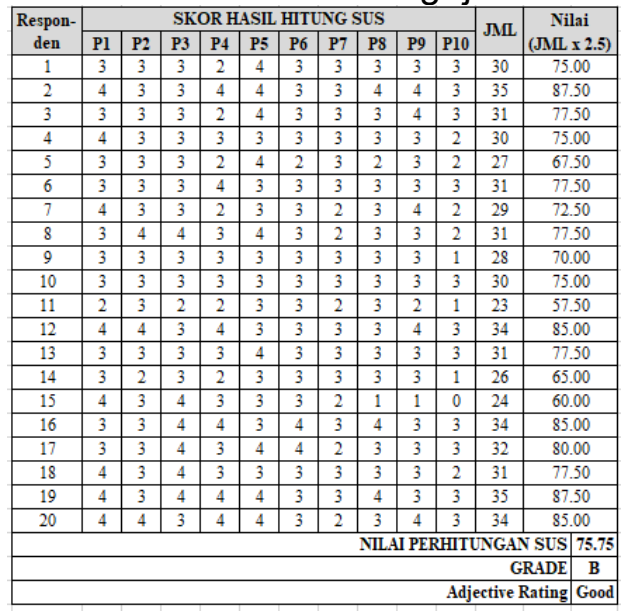

Berdasarkan hasil tabulasi data pada diperoleh skor untuk pengujian SUS bernilai 75,75 yang berarti grade $\mathrm{B}$. Jika dikonversikan menurut standar John Brooke maka prototype KMS RSU Bintang memiliki usability Good menurut para responden.

\section{SIMPULAN DAN SARAN}

1. Simpulan

Berdasarkan hasil penelitian yang dilakukan penulis pada RSU Bintang, maka dapat ditarik kesimpulan sebagai berikut.

a. Pengkombinasian metode perancangan yang dimiliki Fernandez dan Sabherwal serta Amrit Tiwana dengan pendekatan faktor kontingensi dapat diterapkan dengan hasil yang baik, sehingga dapat digunakan sebagai acuan pengembangan. 
b. Hasil analisa dengan pendekatan kontingensi didapatkan task uncertainty bernilai low, task interdependence bernilai hight, pengetahuan mengarah ke procedural dan tacit, ukuran organisasi temasuk organisasi small, strategi bisnis yang digunakan adalah low cost, dan environmental uncertainty bernilai low.

c. Proses KMS yang dikembangkan adalah exchange, direction, socialization for knowledge shering, externalization, routines, combination, dan socialization for knowledge discovery.

d. Fitur KMS yang dihasilkan untuk mendukung KMS pada RSU Bintang adalah dokumentasi artikel/berita, forum diskusi, manajemen document dan manajemen pengetahuan.

e. Infrastruktur yang dimiliki oleh RSU Bintang untuk mendukung pengembangan KMS sudah sangat mendukung.

f. Uji coba fitur yang dimiliki rancangan prototype KMS pada RSU Bintang dilakukan oleh pakar, kepala bagian, komite dan pegawai. Untuk metode UAT menunjukkan bahwa rancangan sudah sesuai dengan kebutuhan untuk pengelolaan pengetahuan. Sedangkan untuk usability mendapat predikat baik.

g. Rancangan KMS hanya untuk mendukung pegawai dalam berbagi pengetahuan dan menjaga pengetahuan yang dimiliki organisasi.

2. Saran

Berdasarkan hasil penelitian yang dilakukan penulis pada RSU Bintang, maka dapat disampaikan saran sebagai berikut.

a. KMS sebaiknya dikembangkan dan diimplementasikan pada RSU Bintang sehingga pengetahuan yang ada dapat dikelola dengan baik dan tidak hilang.

b. Sebelum dikembangkan dan diimplementasikan sebaiknya pihak RSU Bintang melakukan evaluasi terhadap kesiapannya, mulai dari kebijakan, lingkungan fisik, komitmen dan budaya organisasi sehingga KMS dapat dimaksimalkan.

c. Jika sudah diimplementasikan pada RSU Bintang sebaiknya melakukan evaluasi berkala terhadap dampak yang dihasilkan.

d. Memperluas ruang lingkup penelitian pada seluruh bagian yang dimiliki RSU Bintang, sehingga pemanfaatanya lebih optimal.

e. Dalam pengembangan KMS selanjutnya sebaiknya pendekatan yang dilakukan bukan hanya dari proses KM tetapi dari strategi organisasi yang dimiliki.

f. Masih diperlukannya pengujian untuk pengetahuan yang sudah tersimpan, sehingga diketahui efektifitas pengetahuan tersebut.

g. Dapat dijadikan acuan dan perbandingan untuk penelitian selanjutnya serta memperkaya ilmu pengetahuan untuk penelitian sejenis, terutama bagi RSU Bintang.

\section{DAFTAR PUSTAKA}

[1] Alroobaea, R. dan Mayhew, P. J. "How many participants are really enough for usability studies?," Proceedings of 2014 Science and Information Conference, SAI 2014, (August), hal. 48-56. doi: 10.1109/SAI.2014.6918171.

[2] Artifasari, A. Pengaruh Faktor Knowledge Management Terhadap Kinerja Petugas Pada Rumah Sakit Umum Daerah Tenriawaru Bone. Volume 4 Nomor 1 Tahun 2014. ISSN : 2302-1721.

[3] Awad, Elias M., dan Hassan M. Ghaziri.. Knowledge Management. 
Virginia: International Technology Group, Ltd Publication.

[4] Becerra-Fernandez, I., Gonzalez, A. \& Sabherwal, $\quad$ R.. Knowledge Management: Challenges, Solutions, and Technologies. New Jersey: Pearson/Prentice Hall. 2004.

[5] Becerra-Fernandez, I. \& Sabherwal, R.. Knowledge Management: System and Processes. New York: M.E. Sharpe, Inc. 2010.

[6] Borousan, Ehsan, et al.. A Case Study of Implementing Knowledge Management System in Healthcare in Malaysia. International Journal of Research in Management and Technology, ISSN: 2249-9563, Vol. 2, No. 5. 2012.

[7] Jennex, M. E.. Knowledge Management: Concept, Methodologies, Tools and Application. Hershey: Information Science Reference. 2018.

[8] Kharis dkk. Evaluasi Usability Pada Sistem Informasi Pasar Kerja Menggunakan System Usablity Scale (SUS). 2019.

[9] Munir. Kurikulum Berbasis Teknologi Informasi dan Komunikasi. In Journal of Chemical Information and Modeling (Vol. 53, Issue 9). 2018. https://doi.org/10.1017/CBO978110741 5324.004.

[10] Nonaka, I., von Krogh, G, and Voelpel, S. Organizational Knowledge Creation Theory: Evolutionary Paths and Future Advances. Organizational Studies, 27(8), 1179-1206. 2006.

[11] Peraturan Menteri Kesehatan no 71 Tahun 2013 pasal 3 tentang penyelenggara pelayanan kesehatan dan pemilihan fasilitas kesehatan bagi pengguna Kartu Indonesia Sehat.

[12] Peraturan Pemerintah Republik Indonesia No 39 Tahun 2012 tentang penyelenggaraan kesejahteraan sosial.

[13] Tiwana, Amrit.. The Knowledge Management Toolkit, 1st Edition. New Jersey: Prentice Hall. 1999.

[14] Tiwana, Amrit. The Knowledge Management Toolkit, The Practical
Techniques For Building A Knowledge Management System. New Jersey: Prentice Hall. 2000.

[15] Wijayanti, Perancangan Knowledge Management System: Studi Kasus RSUD Pasar Rebo Jakarta Program Studi Magister Teknologi Informasi Universitas Indonesia. 2016. 